\title{
Using individual farm management plans to manage land use change effects associated with new irrigation development, Canterbury, New Zealand
}

\author{
B. Ellwood ${ }^{1}$, L. Mead ${ }^{1}$, C. Mulcock ${ }^{2} \&$ S Dawson ${ }^{3}$ \\ ${ }^{I}$ Meridian Energy Ltd, PO Box 2454, Christchurch, New Zealand \\ ${ }^{2}$ Mulgor Consulting Ltd, PO Box 13240, Christchurch, New Zealand \\ ${ }^{3}$ Boffa Miskell Ltd, PO Box 110, Christchurch, New Zealand
}

\begin{abstract}
Managing the environmental effects arising from intensive agriculture has become a key issue in obtaining permission to abstract water for irrigation in New Zealand. Hunter Downs Irrigation (HDI) is a proposed irrigation scheme that would divert approximately $20 \mathrm{~m}^{3} / \mathrm{s}$ of flow from the Waitaki River to 40,000 hectares of lands in Canterbury, New Zealand. In addition to carrying out extensive assessments of potential environmental effects of the proposed scheme, it also needed to demonstrate how it would be able to implement and maintain ongoing environmental management of irrigated agriculture.

Many of the effects arising from the new development are not readily quantifiable in advance, as they depend on the particular mix of land uses that will be established once the scheme is commissioned. These may also change over time as they will depend not only on the biophysical environment (soils, topography, climate etc.) but also on market drivers and other economic signals.

As the area supplied by this scheme is suitable for a range of land uses, the challenge was to provide sufficient certainty to regulatory agencies and to the public that adverse environmental effects generated by the irrigation scheme will be minimised and that poor practices can either be avoided or can be identified and remedied. At the same time farmers needed to have sufficient flexibility to develop a wide range of agricultural enterprises. To achieve this an environmental management system was developed that requires each farmer to develop and use an environmental farm management plan that is linked to a rigorous audit and compliance regime, and continuous improvement process, so that farmers maintain up to date practices and by doing this it is assumed that the environmental effects are the lowest possible for an irrigated agricultural system. Keywords: Environmental Management System (EMS), irrigation management.
\end{abstract}




\section{Background}

\subsection{Irrigation in New Zealand}

New Zealand has approximately 475,000 ha of irrigated agriculture and this is predicted to almost double by the year 2013 [1] under one scenario modelled. Most of the existing irrigated area $(60 \%)$ is found on the east coast of the South Island of New Zealand in the Canterbury region.

Hunter Downs Irrigation scheme is a proposed pumped irrigation scheme which would have the capacity to irrigate 40,000 ha of land in south Canterbury (Figure 1). The scheme would take approximately $20 \mathrm{~m}^{3} / \mathrm{s}$ of surface water from the Waitaki River (mean flow $368 \mathrm{~m}^{3} / \mathrm{s}$ ) immediately to the south.

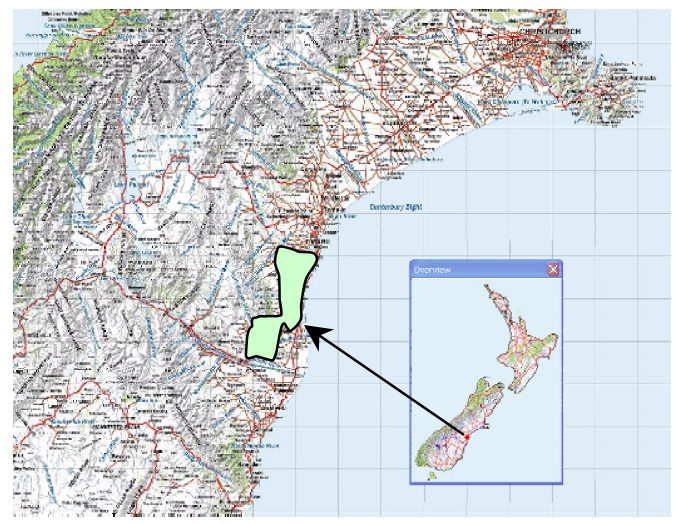

Figure 1: Hunter Downs irrigation Scheme area schematic [6].

The scheme requires authorisation under the Resource Management Act (RMA) 1991. To obtain consents the developers are required to describe their proposal and show both to authorities and the public how adverse environmental effects can be avoided, remedied or mitigated.

\subsection{Environment effects management approach}

To determine the effects of the proposed taking of water and using it for irrigation, the HDI scheme promoters commissioned extensive assessments of the existing environment and used models to predict the magnitude of the changes that could occur with development of the scheme, looking at the effects of both the abstraction from the Waitaki River and the use of the water for irrigated agriculture.

The models for predicting the effects of using the water for irrigated agriculture made assumptions about the land use types that would arise in this region with irrigation (Table 1). However, there is no certainty that this is the land use mix that would actually occur as the soils and climate are suitable for a 
Table 1: $\quad$ Current and modelled land use in the HDI command area.

\begin{tabular}{|l|c|c|}
\hline Land Use & $\begin{array}{c}\text { Proportion of Total Area } \\
\text { Dry Land }\end{array}$ & $\begin{array}{c}\text { Proportion of Total } \\
\text { Area } \\
\text { Irrigated }\end{array}$ \\
\hline Dairy & $6 \%$ & $46 \%$ \\
\hline Arable & $14 \%$ & $19 \%$ \\
\hline Sheep & $58 \%$ & $18 \%$ \\
\hline Beef & $5 \%$ & $7 \%$ \\
\hline Deer & $12 \%$ & $4 \%$ \\
\hline Dairy Support & $2 \%$ & $7 \%$ \\
\hline
\end{tabular}

range of farm types and the relative profitability of different enterprises will change over time.

To be able to demonstrate that the scheme can mange the environmental effects of any land use mix that might eventuate an Environmental Management System (EMS) approach was adopted.

The proposed EMS system took the industry environmental standards that are widely agreed as best practice standards in NZ today, and incorporated the principles of continuous improvement to enable standards, and hence on-farm practices, to be revised as understanding increases over time. This enables adverse effects on the downstream receiving environment of the scheme to be minimised while maintaining flexibility of land use to optimise the benefits and opportunities.

The approach adopted with the HDI scheme takes the direction promoted by national policy discussion documents in New Zealand including the Parliamentary Commissioner for the Environment's 'Growing for Good' report [2] and "Freshwater for the Future: a supporting document for the Government's Sustainable Water Programme of Action" [3]. These reports both look towards the need to achieve irrigation performance in NZ that is clearly sustainable. "Growing for Good" signals clearly that if New Zealand wishes to remain competitive in the food and fibre industries and become more environmentally sustainable then it is not 'business as usual' for our land-based enterprises. The report focuses on the importance of two key inputs to farming productivity nitrogen fertiliser and irrigation water. It notes that although these are fundamental to agricultural production, they also have major potential to result in adverse impacts. Therefore NZ must find innovative new directions for managing these vital inputs.

"Freshwater for the Future" points, among other matters, to the need for more efficient water use and catchment management, including more accurate information on water takes and use, and improved management of undesirable effects of land use on water quality. It identifies the need to ensure that tools and knowledge developed from science are integrated into individual rural business decisions. 


\section{EMS in New Zealand and Australian agriculture}

Generally the EMS approaches that have been developed for agriculture in NZ and Australia have been designed as 'process' standards that can be readily integrated with other on-farm management processes and records that landholders may already maintain, such as financial accounts, food safety, occupational health and safety, and quality assurance.

In Australia use of EMS in agriculture, both on-farm and in agricultural industries is promoted and supported at government level [4] whereas in NZ use of EMS has been primarily market driven and developed by the sector concerned. In both countries the use of an EMS process is voluntary.

A number of the farm environment related codes of practice and guidelines developed in New Zealand take the EMS 'plan, act, review, revise' approach. For example: the "Code of Practice for Nutrient Management (with emphasis on fertiliser use)" [5]; the kiwifruit industry "KiwiGreen" and wine grape "Sustainable Winegrowing New Zealand" program. In New Zealand an operative irrigation company has just developed mandatory Environmental Farm Plan requirements and audit process required by their consent conditions.

With the EMS approach there are opportunities for farm businesses to be innovative in both their land use enterprises and their environmental management. The EMS approach also provides a continuous, rather than discrete adoption of new practices / technologies.

\section{Key on-farm environmental management issues for HDI}

It was identified through workshops and meetings between the scheme developers, farmers, scientist and environmental groups, that there are six key environmental management issues related to the on-farm effects of irrigated land use for the HDI scheme area, table 2 .

Managing each of the activities and the associated issues listed in table 2 at an appropriate level allows water users to adapt the farming systems used. Two examples of the land use mix in the HDI command area are shown in table 1 a dry (unirrigated) land use mix and an irrigated system land use mix. The irrigated system example is predominately a pastoral based system. This could easily shift to a more arable system if the relative economics for either system changed. There are different potential outputs to the environment from different farming systems i.e. a pastoral system vs. an arable dominated system. As discussed earlier, the exact mix of land use types is not known, therefore a system which can adapt over time is required.

\subsection{The farm management plans used for HDI}

Each of the six management areas listed in table 2, covered in the HDI Farm Management Plan (FMP) has a similar template covering the management objective, and the key potential problems that the water user will avoid, remedy 
Table 2: $\quad$ Farm Management Plan key activities, potential environmental concerns and measures to mitigate or avoid.

\begin{tabular}{|c|c|c|}
\hline Activity & $\begin{array}{c}\text { Key environmental } \\
\text { concerns/ } \\
\text { Potential impacts }\end{array}$ & $\begin{array}{c}\text { Examples of Best Management } \\
\text { Practices }\end{array}$ \\
\hline $\begin{array}{l}\text { Irrigation } \\
\text { management }\end{array}$ & $\begin{array}{l}\text { Wasteful use of water e.g. } \\
\text { - } \quad \text { irrigation during/after } \\
\text { - } \quad \text { painfall } \\
\text { ponding of irrigation } \\
\text { - } \quad \text { inater } \\
\text { - } \quad \text { drainage to other } \\
\quad \text { properties }\end{array}$ & $\begin{array}{l}\text { Use INZ code of practice for design } \\
\text { Use INZ evaluation code } \\
\text { Schedule \& apply water taking into } \\
\text { account: crop type, soil type, rainfall etc } \\
\text { Soil moisture monitoring }\end{array}$ \\
\hline $\begin{array}{l}\text { Soil } \\
\text { management }\end{array}$ & $\begin{array}{ll}\text { - } & \text { Soil compaction / } \\
& \text { pugging } \\
\text { - } & \text { Soil erosion } \\
\text { - } & \text { Soil health problems } \\
\text { - } & \text { Soil contamination }\end{array}$ & $\begin{array}{l}\text { Avoid stock pugging - use stand off } \\
\text { pads or 'sacrifice' paddock } \\
\text { Use shelter planting \& reduced tillage to } \\
\text { avoid wind erosion } \\
\text { Avoid irrigation during or after heavy } \\
\text { rainfall to minimise runoff to avoid } \\
\text { erosion \& contamination of water } \\
\text { Use only FertMark certified fertilisers to } \\
\text { minimise soil contamination }\end{array}$ \\
\hline $\begin{array}{l}\text { Nutrient } \\
\text { management }\end{array}$ & $\begin{array}{l}\text { - Fertiliser getting into } \\
\text { ground \& surface } \\
\text { waterways } \\
\text { - } \text { Runoff and leaching of } \\
\text { stock effluent from } \\
\text { paddocks into water } \\
\text { ways (including } \\
\text { through tile \& mole } \\
\text { drains) }\end{array}$ & $\begin{array}{l}\text { Follow the NZ code of Practice for } \\
\text { Nutrient Management } \\
\text { Use soil test results to plan fertiliser } \\
\text { needs } \\
\text { Use Nutrient budgeting \& nutrient } \\
\text { management } \\
\text { Manage fertiliser applications e.g. to } \\
\text { avoid waterways, timing re crop needs, } \\
\text { rainfall etc. }\end{array}$ \\
\hline $\begin{array}{l}\text { Collected } \\
\text { animal } \\
\text { effluent } \\
\text { management }\end{array}$ & $\begin{array}{l}\text { Contamination of ground \& } \\
\text { surface water during } \\
\text { disposal of collected animal } \\
\text { effluent (e.g. dairy shed or } \\
\text { piggery waste) }\end{array}$ & $\begin{array}{l}\text { Preparing an effluent disposal plan, } \\
\text { including spillage management } \\
\text { Including nutrients from effluent in } \\
\text { nutrient budget and management } \\
\text { Include effluent irrigation in total } \\
\text { irrigation management }\end{array}$ \\
\hline $\begin{array}{l}\text { Riparian } \\
\text { management }\end{array}$ & 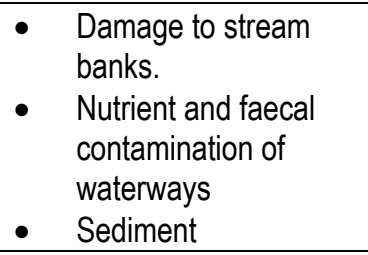 & $\begin{array}{l}\text { Stock management, including fencing } \\
\text { to keep stock from waterways } \\
\text { Crop management, including buffer } \\
\text { zone around waterway } \\
\text { Stream bank planting }\end{array}$ \\
\hline
\end{tabular}


Table 2: $\quad$ (Continued).

\begin{tabular}{|c|c|c|}
\hline $\begin{array}{l}\text { Biodiversity } \\
\text { \& Ecosystem } \\
\text { management }\end{array}$ & $\begin{array}{l}\text { - Loss of native plants } \\
\text { and animals and their } \\
\text { habitats } \\
\text { - Loss of ecosystem } \\
\text { diversity } \\
\text { - Soil health problems }\end{array}$ & $\begin{array}{l}\text { Protect existing habitats (e.g. wetlands) } \\
\text { as an integral part of farm } \\
\text { management } \\
\text { Plantings (native \& exotic) to support } \\
\text { ecosystem diversity }\end{array}$ \\
\hline
\end{tabular}

or mitigate. The six templates then list the scheme 'requirements'. These are matters that are mandatory for all water users to achieve if they wish to receive water from the scheme.

The next part of each template lists the areas where water users need to implement best management practices to manage and minimise potential environmental impacts. Each user must consider each topic in relation to their specific property (e.g. soil type, slope, irrigation method, irrigated area, land uses) and determine how they will achieve best practice and what monitoring and records they will use to show their achievements. For example soil moisture measurements in a cropping system may be through use of an irrigation consultant who provides a measurement and analysis service, whereas pasture systems for dairy may have permanent soil moisture equipment that is monitored by farm staff.

Figure 2 is an example of the FMP template for Waterway and Riparian Management.

\subsection{How the HDI farm management plan fits an EMS framework}

The environmental management of the HDI scheme has several layers of environmental control. The overall scheme has resource consent conditions administrated by the Regional Council, and a Scheme Management Plan (SMP) which details how the conditions of consent are met and how the scheme is operated to meet those requirements. The SMP details the requirement for the FMP's and how the irrigation scheme management will provide training, FMP review, auditing and then, if necessary, compliance and enforcement of requirements. Compliance and enforcement will be undertaken by the HDI scheme management and if necessary the Regulatory Authority. The FMP is the third layer of the HDI scheme management structure. Under the structure each water user in the HDI scheme will prepare and implement an FMP tailored to that property's land use type at that time. The water users and ultimately the scheme management must demonstrate to the Regulatory Authority how the use of natural resources is being actively managed in order to minimise environmental impact while optimising productive output from irrigation.

The use of the HDI environmental plans structure provides a framework within which best practices can be implemented on farm to achieve a high level of environmental protection and enhancement. The FMP is designed so that it 


\section{Waterway \& Riparian management}

Our objective is to protect the waterways on our farm by maintaining healthy riparian margins.

The problems that we will avoid, remedy or mitigate include:

- Stock damage to banks, causing sedimentation

- Contamination of water by stock or agrichemicals

- Sail loss causing sedimentation of waterways

- Poor water quality and stream life

We will comply with HDP's specific requirements relating to waterway and riparian management which include:

\begin{tabular}{|l|c|c|}
\hline HDI requirements & \multicolumn{2}{c|}{$\begin{array}{c}\text { Checklist } \\
\text { Yes }\end{array}$} \\
\hline Figarian management to meet HDI quideines (Aggend & \multicolumn{1}{c|}{ No) for all permanent streams } \\
\hline & & \\
\hline
\end{tabular}

In addition we will implement our own management policies to achieve the above objectives including:

\begin{tabular}{|c|c|}
\hline $\begin{array}{l}\text { We will incorporate the following in our waterway \& riparian management \& } \\
\text { practices }{ }^{4}\end{array}$ & $\begin{array}{l}\text { Checklist } \\
\text { Yes No }\end{array}$ \\
\hline \multicolumn{2}{|l|}{ Exclude cartle, pigs and deer from waterwars. Exclude other stock from waterwavs, if necessary. } \\
\hline \multicolumn{2}{|l|}{$\begin{array}{l}\text { Leave a buffer of uncutivated vegetation beside streams to filter any runoff. This wil be an } \\
\text { appropriate distance from the stream bank depending on soil type etc. [ECAN has guidelines] }\end{array}$} \\
\hline \multicolumn{2}{|l|}{$\begin{array}{l}\text { Allow a wider buffer at low points which are mare prone to potential runoff from paddocks to provide } \\
\text { fltter. }\end{array}$} \\
\hline \multicolumn{2}{|l|}{ Have field drains discharge into a riparian strip, rather than a waterway where practical. } \\
\hline \multicolumn{2}{|l|}{ When apphing fertiliser or other chemicals soread at a dstance where it wont cet into the waterway. } \\
\hline \multicolumn{2}{|l|}{ Manage farm drains and races according to quideines (Appendix 10) } \\
\hline $\begin{array}{l}\text { Help manage waterways with plantings of suitable trees and shrubs an waterway margins, choosing } \\
\text { species acconding to quidelines (e.q. regional counci) (Appendix 10) }\end{array}$ & \\
\hline
\end{tabular}

\section{Self Assessment}

Does my management achieve the objectives above?

Yes $\square \quad$ Objectives achieved

No $\quad \square \quad$ Please fill out table below

\begin{tabular}{|l|l|l|l|}
\hline Liat actions required & Person reaponsible & $\begin{array}{c}\text { Timeframe for } \\
\text { completion }\end{array}$ & $\begin{array}{c}\text { Completion } \\
\text { date }\end{array}$ \\
\hline & & & \\
\hline & & & \\
\hline & & & \\
\hline & & & \\
\hline
\end{tabular}

\section{Verification}

The information crovided is verified as correct.

Property owner I manager

Signature

Date

\footnotetext{
${ }^{1}$ Note that this section refers only to waterwsys on or directly affected by the property that the plan app bies to.
}

Figure 2: $\quad$ Waterway and Riparian management template.

can be adapted for each farm business. Many of the requirements will have both economic and environmental benefits. 
The FMP of individual farms are required to be reviewed and independently audited to ensure that the best practice for the current land use mix undertaken on the irrigated property is being achieved and thus adverse effects off farm can be minimised. The audits will identify poor practice and require practices be improved for the water supply to continue.

\section{Discussion}

The FMP details were presented as a major supporting management tool at the HDI scheme resource consent hearings held in late 2007 to show how the HDI scheme would be able to minimise the land use intensification effects from the use of water for irrigated agriculture. While no decision has been received on the HDI hearings at the time of writing, the approach taken with the FMP's is significantly more detailed than any plans or conditions of consent offered before in New Zealand for irrigation consent.

The FMP's at the farm level are designed so different land use practices can be accommodated within the scheme. This is the advantage of using plans instead of strict conditions of consent which prescribe and limit the activities which can be undertaken.

The use of FMP's links the HDI scheme in an EMS which can adapt and adopt new technologies as they arise over time. The alternative to EMS would mean that as new practices evolved new consents or variations to existing consents would be required. In New Zealand this is not favoured because the consenting system under the RMA is very expensive and time consuming. If the scheme's resource consents were subject to continual major change this would increase the uncertainty of water availability and reduce the farmer willingness to invest either in the scheme as a whole or in new technologies.

Even if the regulatory authorities accept the approach, there will still be a number of challenges to face, including the actual development of each individual FMP and the ongoing compliance and enforcement to ensure that FMP's are implemented, and sound environmental outcomes do occur on the ground.

\section{Conclusions}

Using an EMS approach to manage the environmental effects of irrigated land use is a new concept for irrigation schemes in NZ. Because it is a process rather than a set of rules or prescribed practices the approach provides individual farmers with the flexibility to be innovative in their agricultural enterprises while regulatory authorities, environmental groups and others can be assured that the irrigation scheme managers have a rigorous and ongoing approach to achieving good environmental management that includes the means to address problems that may arise.

With independent audits and compliance monitoring of water users individual FMP, the HDI scheme is likely to achieve the highest benefits irrigation can 
bring to the farmer and the region while minimising the impact on the environment when compared with existing irrigation schemes in New Zealand.

Successful implementation will be dependent on all parties with an interest in the management of natural resources and agricultural production working together so that certainty of adopting best sustainable practices is achieved and therefore the potential adverse environmental effects arising from land use intensification are minimised.

\section{References}

[1] MAF Technical PaperNo:04/01 The Economic Value of Irrigation In New Zealand, Ministry of Agriculture and Forestry, Wellington, New Zealand, 2004.

[2] PCE, Growing for good: intensive farming, sustainability, and New Zealand's environment. Parliamentary Commissioner for the Environment. Wellington, New Zealand, 2005.

[3] MFE, Freshwater for the Future: a supporting document- a technical information paper outlining the key outcomes for the sustainable management of New Zealand's freshwater. Ministry for the Environment, Wellington, New Zealand, 2006.

[4] Australia's National Framework for Environmental Management Systems in Agriculture, 2002.

[5] Code of Practice for Nutrient Management (with emphasis on fertiliser use) NZFRMA, Fert Research, Auckland, New Zealand, 2007.

[6] Land Information New Zealand 260-J40 New Zealand Map Grid Projection, Wellington New Zealand, 2001. 